\title{
Mangroves of Colombia revisited in an era of open data, global changes, and socio-political transition: Homage to Heliodoro Sánchez-Páez
}

\author{
(1) Juan F. Blanco-Libreros ${ }^{1, *}$, 강 Ricardo Álvarez-León ${ }^{2}$ \\ ${ }^{1}$ Instituto de Biología, Universidad de Antioquia, Medellín, Colombia \\ ${ }^{2}$ Fundación Verdes Horizontes, Manizales, Colombia
}

\begin{abstract}
Colombia is the only South American country with coasts in both the Pacific Ocean and the Caribbean Sea thus providing great contrasts for mangroves in terms of climatic types and geomorphic settings. For instance, mangroves are extensive along the Pacific coast due to both high annual rainfall rates and the presence of many world-class deltas. Besides, they are the habitat of the only Neotropical endemic mangrove (Pelliciera rhizophorae), which is also a threatened species. In contrast, mangroves are discontinuously distributed along the Caribbean coast and they are extensive in the three major deltas and a few coastal lagoons. In addition, dwarf and stunt mangroves are found in northern arid lands sprung by seasonal streams and rivers. Recent studies have highlighted the global significance of the Colombian mangroves in terms of their extension, low deforestation rates (particularly in the Pacific coast), and high reservoirs of ecosystem carbon scattered nation-wide. Nonetheless, most of the current understanding of the biogeography of our mangroves has been obtained by integrating studies independently conducted in different sites and years. The voluminous information collected by Heliodoro Sánchez-Páez and his colleagues in the largest national inventory of mangroves (MCP: Mangroves of Colombia Project, Ministry of the Environment) undertaken in the mid 1990's provides an opportunity to re-assess biogeographic hypotheses (e.g., that high rainfall promotes the increase in the importance value of red mangroves) and to explore macroecological patterns when combined with open data sets. The objective of this paper was to introduce HELIO_SP.CO v.1, an open database derived from this mangrove inventory as a homage to Heliodoro Sánchez-Páez, who passed away in 2017, as a platform for macroecological studies and benchmark for future impact assessments of climate change and land-use change on mangroves in Colombia. In addition, the contributions of the MCP were reviewed and the general geographic patterns were explored by using HELIO_SP.CO v.1. For instance, the shift of the two dominant mangrove species in Colombia across the rainfall gradient observed from Nariño to La Guajira was clearly depicted. Using WorldClim 2, we also explored the rainfall and temperature spaces where the species occur. Finally, we briefly reviewed the progress of mangrove science since 1997 and identified some challenges regarding climate change and post-armed conflict scenarios in Colombia. (C) 2019. Acad. Colomb. Cienc. Ex. Fis. Nat.
\end{abstract}

Key words: Biogeography; macroecology; Rhizophora spp.; Avicennia germinans; Laguncularia racemosa; Pelliciera rhizophorae; HELIO SP.CO v.1; Climatic space; Post-conflict.

Regreso a los manglares de Colombia en una era de datos abiertos, cambios globales y transiciones sociopolíticas: homenaje a Heliodoro Sánchez-Páez

\section{Resumen}

Colombia es el único país suramericano con costas tanto en el Océano Pacífico como el Mar Caribe, por lo cual exhibe grandes contrastes para los manglares en términos de tipos de climas y geoformas costeras. Por ejemplo, los manglares son extensos a lo largo de la costa del Pacífico debido a la alta precipitación anual y a la presencia de grandes deltas. Estos manglares son el hábitat de la única especie endémica del Neotrópico (Pelliciera rhizophorae), también clasificada como amenazada. En contraste, los manglares se distribuyen de forma discontinua a lo largo de la costa Caribe, siendo extensos en los tres deltas más grandes y en unas pocas lagunas costeras. Además, los manglares enanos y de baja estatura están presentes en las zonas áridas de la costa norte, bañadas por quebradas y ríos estacionales. En estudios recientes se resalta la importancia global de los manglares de Colombia en términos de su extensión, sus bajas tasas de deforestación (particularmente en la costa Pacífica) y sus grandes reservas de carbono. Sin embargo, la mayor parte de lo que actualmente sabemos de la biogeografía de los manglares colombianos se ha obtenido a partir del análisis de estudios independientes llevados a cabo en diferentes sitios y años. La voluminosa

\footnotetext{
*Corresponding autor:

Juan F. Blanco-Libreros; juan.blanco@udea.edu.co; Received: October 25, 2018; Accepted: March 2, 2019; Editor: Jaime Cantera
} 
información recolectada por Heliodoro Sánchez-Páez y sus colaboradores en el mayor inventario nacional de manglares (PMC: Proyecto Manglares de Colombia, Ministerio del Medio Ambiente) recopilado a mediados de la década de 1990, ofrece una oportunidad para, en combinación con datos abiertos, revisar hipótesis biogeográficas (por ejemplo, que la alta precipitación promueve el valor de importancia del mangle rojo) y explorar patrones macroecológicos. En homenaje a Heliodoro Sánchez-Páez (fallecido en el 2017), se presenta a la comunidad la base de datos HELIO_SP.CO v.1, derivada de este inventario forestal, como una plataforma para los estudios macroecológicos y línea de base para futuras evaluaciones del impacto del cambio climático y en los usos de la tierra. Se revisaron las contribuciones del PMC y se exploraron patrones geográficos generales utilizando la base de datos HELIO_SP.CO v.1. En este sentido, se describió el recambio de las dos especies dominantes a lo largo del gradiente de precipitación observado desde Nariño hasta La Guajira. Se utilizaron datos rasterizados de WorldClim 2 para explorar los espacios de precipitación y temperatura donde las especies fueron registradas. Por último, se revisó brevemente el progreso de las "ciencias del manglar" desde 1997 y se detectaron algunos de los desafíos relacionados con el cambio climático y las situaciones posteriores al acuerdo de paz en Colombia.

Palabras clave: Biogeografía; Macroecología; Rhizophora spp.; Avicennia germinans; Laguncularia racemosa; Pelliciera rhizophorae; HELIO_SP.CO v.1; Espacio climático; Postconflicto.

\section{Introduction}

For almost two decades we had been planning to review the data obtained from the largest mangrove inventory done in Colombia to date (Sánchez-Páez, et al., 1997 a, b), but despite an extended abstract and exploratory analyses in theses required for graduation (Estrada-Urrea, et al., 2010), the raw dataset of this inventory has remained inaccessible to the scientific community and no in-depth analysis has been performed. However, the passing of the senior forester Heliodoro Sánchez-Páez in February 12, 2017, prompted us to finish the data mining and assembling the geographical database to serve national and international researchers in an era of new scenarios (climatic, socioeconomic, and political) in Colombia that will require open access to nation-wide baseline data. Heliodoro Sánchez-Páez was the director of the National Park Division in the former Instituto Nacional de los Recursos Naturales Renovables y del Ambiente (Inderena), prior to the creation of the Colombian Ministry of the Environment in 1993. In this post, he was instrumental for the designation of various protected areas including the Salamanca Park, a mangrove landmark area in the Caribbean coast of Colombia. He also worked as a university professor and editor of a national forestry journal (Colombia Forestal), and most importantly, he was the leading scientist responsible for the largest national inventory of mangroves undertaken until now in the country by the Ministry of the Environment with funding from the International Tropical Timber Organization (IITO) (Sánchez-Páez, et al., 1997a,b). The Mangroves of Colombia Project (MCP) was executed in two phases between 1991 and 2001 and it was key for updating the extent of mangroves of the country, empowering fishing communities, initiating pilot restoration projects, and drafting a national policy. Nearly three decades after the initiation of the MCP, we finally wrote this review paper with the following objectives: 1) to highlight the uniqueness of mangroves in Colombia and their global significance; 2) to briefly explain the major achievements of the MCP, and 3) to promote the use of the MCP databases to address the main challenges before researchers and managers during the coming decades in a scenario of sea level rise and climate change, pervasive land-use conflicts, and coastal zone planning after the cessation of a 50 year armed conflict through the agreement signed with the largest insurgent group (Fuerzas Armadas Revolucionarias de Colombia, FARC) in November 2016. For this purpose and as a tribute to Heliodoro Sánchez-Páez, we released the geographical database HELIO_SP.CO v.1: Hierarchical, Entity-based and Landscape-level Information Observatory for Mangrove SPecies in COlombia, version 1. This database contains stand density, mean diameter at breast height (DBH), and Importance Value Index (IVI) for the four most important species (Rhizophora spp., Rhizophoraceae; Avicennia germinans, Avicenniaceae; Laguncularia racemosa, Combretaceae, and Pelliciera rhizophorae; Tetrameristaceae) in nearly 100 plots located in the Colombian mainland departments (four in the Pacific coast and seven in the Caribbean coast). Sampling was conducted between November 1995 and August 1996 in both coasts. Mean and maximum tree heights were also included for the Caribbean coast. The plots extended between 1.41 and 12.23 degrees in latitude in the Northern Hemisphere (WGS84 System). This is a first version as we only included the data for trees with $>15 \mathrm{~cm}$ in diameter. We also included a climatic dataset for the locations extracted from gridded climatic data, a current standard for studies in mangrove macroecology (Rivera-Monroy, et al., 2017, Osland, et al., 2018; see further descriptions in Supplementary file, https://www.raccefyn.co/index.php/raccefyn/article/ downloadSuppFile/780/3362 and data repository at https:// doi.org/10.7910/DVN/GGLRXW). Additionallly, we briefly reviewed the progress in mangrove science in Colombia since 1997 by highlighting the most significant studies.

\section{Global significance of the mangroves of Colombia}

Colombia can be described as a unique and globally significant country in terms of mangroves. It is the only country in South America with coasts in both the Pacific and the Atlantic Oceans (specifically in the Caribbean Sea), which have physiognomic differences mainly due to significantly 
different annual rainfall rates (Álvarez-León, 1993). In 1992, it was estimated that there were nearly 380,000 ha of mangroves in Colombia (Zambrano-Escamilla \& Rubiano-Rubiano, 1997 a, b), The most recent update of global mangrove extent placed our country in the top 20 world ranking, and in the fourth place in the Americas (Hamilton \& Friess, 2018). Another recent global study on mangrove height placed the country among the top 5, reporting trees that exceed $50 \mathrm{~m}$ in some locations in Cauca and Nariño (Simard, et al., 2019). However, prior to the late 1980s this significance was not reflected in the number of studies published nor in nation-level laws protecting this ecosystem (Álvarez-León \& Álvarez-Puerto, 2016). On the contrary, degradation was commonplace in many locations due to urban sprawl, agricultural and pastoral expansion, establishment of fish and shrimp ponds, and legal and illegal logging, among other threats (ÁlvarezLeón, 1993, Álvarez-León \& Polanía, 1994, 1996). The execution of the MCP updated mangrove extent, promoted the adoption of management policies, and highlighted the importance of mangroves for biodiversity (Álvarez-León \& García-Hansen, 2003). Nowadays, some mangrove areas of Colombia, particularly in the Pacific coast and the Southern Caribbean coast, have been recognized internationally as luxuriant and semi-wild areas (Castellanos-Galindo, et al., 2015, Mejía-Rentería, et al., 2018, López-Angarita, et $a l ., 2018$ ), as well as world-class high biomass and carbon reservoirs (Blanco-Libreros, et al., 2012, 2015, Bolívar, et al., 2017). According to Hamilton \& Friess (2018), 2\% of the global mangrove carbon stock is found in Colombia, and $45 \%$ of this holding is located in Nariño, while another $80 \%$ can be found in the four states of the Pacific coast. Colombia also exhibits a variety of climates ranging from super humid to desert along the South-North latitudinal gradient, thus promoting the development of tall mangroves in Cauca and Nariño, in the vicinity with Ecuador, in the Pacific, and dwarf mangroves in the Guajira Peninsula, in the vicinity with the Maracaibo Gulf in Venezuela (PintoNolla, 1999). Finally, the formation of the Isthmus of Panamá promoted a disjunct distribution of the Piñuelo or Tea Mangrove, Pelliciera rhizophorae, the only endemic species to the Neotropics, presumably under an incipient speciation process due to the genetic isolation between both basins and the small size of the local populations (BlancoLibreros, et al., 2016, Castillo-Cárdenas, et al., 2015). It is also the only Neotropical species considered to be in a vulnerable conservation status (Blanco-Libreros, et al., 2016, and references therein).

\section{The 1991-2001 national inventory (MCP)}

During phase 1 (1991-1995), the aim of the project was to provide the scientific baseline for preserving and managing mangroves bearing in mind that they could be sustainably used for multiple purposes by fishing communities and for the economic development of selected regions. Two large volumes were published summarizing the diagnostics and the zoning of mangroves from each coast (Sánchez-Páez, et al., 1997 a, b). Each volume contained field inventories of the floristic composition and the forest structure, as well as an impact assessment in addition to hydrologic and edaphic information. Descriptions of the major socioeconomic features were also included. The information was compiled for each of the coastal departments (the country's major administrative divisions) (Figure 1). Baseline maps were constructed at a 1:100,000 scale using INTERA RADAR images for the Pacific coast mangroves and Landsat satellite images for the Caribbean coast (Zambrano-Escamilla \& Rubiano-Rubiano, 1997 a, b). Onto these maps, mangroves were preliminarily classified into four categories according to field assessments: 1) preservation, 2) multiple use, 3) recovery, and 4) production. Guidelines were provided for managing mangroves under each zoning category.

In addition to the forest inventory carried out with point-centered quadrats, permanent plots were established nationwide, but only a fraction was revisited. Ten out of 25 permanent plots established along the Caribbean coast were measured twice during the period 1996-1997 (SánchezPáez, et al., 1998a). In the arid to desert parts of the northern coast (Magdalena and La Guajira), sapling colonization was very low while it was greater (particularly in $R$. mangle) in the semi-arid (seasonally-dry) middle coast (Bolívar and Córdoba). In the Pacific Coast, nine permanent plots out of 27 were measured twice during the period 1996-1999 (Sánchez-Páez, et al., 1998 b). The red mangrove R. mangle (mean $\mathrm{DBH}=23.5 \mathrm{~cm}$ ) increased $0.31 \mathrm{~cm} /$ year on average. In the southern part of this coast (Nariño), sapling colonization was also measured.

During phase one, pilot nursery projects $(<1$ yr-span $)$ were initiated to aid restoration of degraded areas (UlloaDelgado, et al., 1998). In the Caribbean, survival of $R$. mangle was high either in nursery $(80-100 \%)$ or in fieldplanted propagules (67-95\%) in Pasacaballos and Leticia (Bolívar), Boca Cerrada and La Caimanera (Sucre), and San Antero and Bahía de Cispatá (Córdoba) (Sánchez-Páez, et al., 1998a). Growth was also measured in various species along the Caribbean. In the Pacific, survival of red mangrove was greater either when transplanted from nurseries or when directly planted in 15 restoration plots distributed along the four coastal states (Guevara-Mancera, 1998, see location in the map in page 6; Sánchez-Páez, et al., 1998 b, table 5, page 57). Outstandingly, the survival of $96 \%$ of the Piñuelo mangrove ( $P$. rhizophorae) seedlings was observed when transplanting from the nurseries to the field. For further detail, we recommend reading the original reports. We are not aware of the continuity of such restoration projects.

During phase two of the project (1999-2000), the aim was to describe the dynamics of mangrove growth by monitoring permanent plots for increments in tree diameter, natural recruitment, and phenology (Sánchez-Páez, et al., 2000, 2004). These efforts were concentrated in 


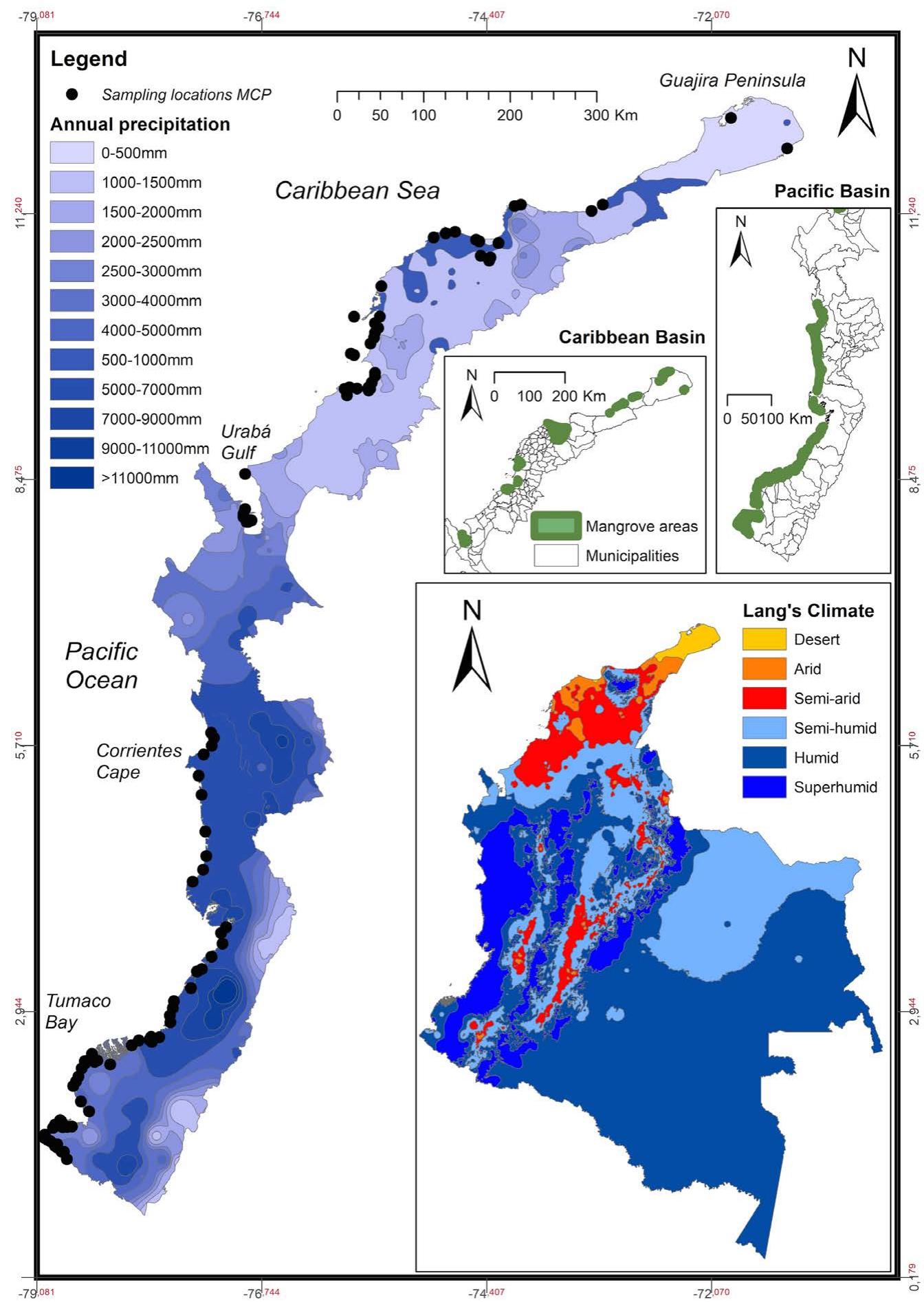

Figure 1. Distribution of sampling locations of the "Mangroves of Colombia Project" along the two Colombian coasts relative to annual precipitation. Large inset: Country map showing Caldas-Lang climate types. Small insets: Mangrove areas according to Etter's Ecosystem Map of Colombia (1998) are shown for both coasts. Climate data from Sistema de Información Ambiental de Colombia (IDEAM-SIAC).

Córdoba. Pilot restoration projects were also established in partnership with local communities to provide the guidelines for successful initiatives using the four most common mangrove species. Productive projects (silviculture) were established (two in Bolívar, one in Sucre, and one in
Córdoba) with former illegal loggers. They were trained in nursery and planting techniques and they were motivated to restore degraded areas. For instance, 80 ha were planted in Canal del Dique, while channels were reopened in Cispatá Bay in order to increase fisheries. In summary, by working 
alongside with the fishing communities, the MCP supported community organization, promoted environmental education, and rescued local ecological knowledge useful for mangrove silviculture and restoration (Sánchez-Páez, et al., 2000, 2004). The second phase produced five books, 30 technical reports, five booklets, two videos, 90 thematic maps $(1: 100,000)$, and six presentations in national and international scientific meetings. Finally, the results from the MCP were used by the Ministry of the Environment for drafting the national mangrove policy and for issuing various ministerial resolutions that are valid to date (Álvarez-León \& Álvarez-Puerto, 2016).

\section{Usefulness of the MCP databases: The example of biogeographical and macroecological patterns}

While the MCP produced voluminous technical reports and robust databases that were employed for zoning mangroves nation-wide and promoted policies for mangrove management at national and local levels, little was applied for advancing scientific knowledge. For this reason, in the present review, we outlined the major patterns based in a new analysis using Geographic Information Systems, which provides additional features for the 292,724 ha of mangroves reported in 1992 for the Pacific coast, and the 87,230 ha for the Caribbean coast (Zambrano-Escamilla $\&$

Rubiano-Rubiano, 1997 a, b). We have redrawn part of the original data (now in HELIO_SP.CO v.1, see supplementary file, https://www.raccefyn.co/index.php/raccefyn/article/ downloadSuppFile/780/3362) and made exploratory correlations with climatic-gridded-data (i.e., WorldClim2) (Fick \& Hijmans, 2017).

Overall, Colombian mangroves were classified phytosociologically as Rhizophorion occidentale, but this scheme has been criticized and it is not commonly used nowadays (Saenger, 2002). This classification is supported by MCP data due to a greater IVI in Rhizophora spp. than in other species regardless of the basin (Figure 2 (Supplementary file, https://www.raccefyn.co/index.php/raccefyn/article/ downloadSuppFile/780/3362, Figure 3). Actually, 75\% of the sampling plots scored an IVI $>100$ in Rhizophora and could be classified as mixed-species forests while selected plots with an IVI $>200$ could be classified as monodominant (sensu Peh, et al., 2011, where a single species contributes $>50 \%$ of abundance). Avicennia germinans was the second most important species, followed by $L$. racemosa and $P$. rhizophorae. Such dominance by Rhizophora spp. is linked

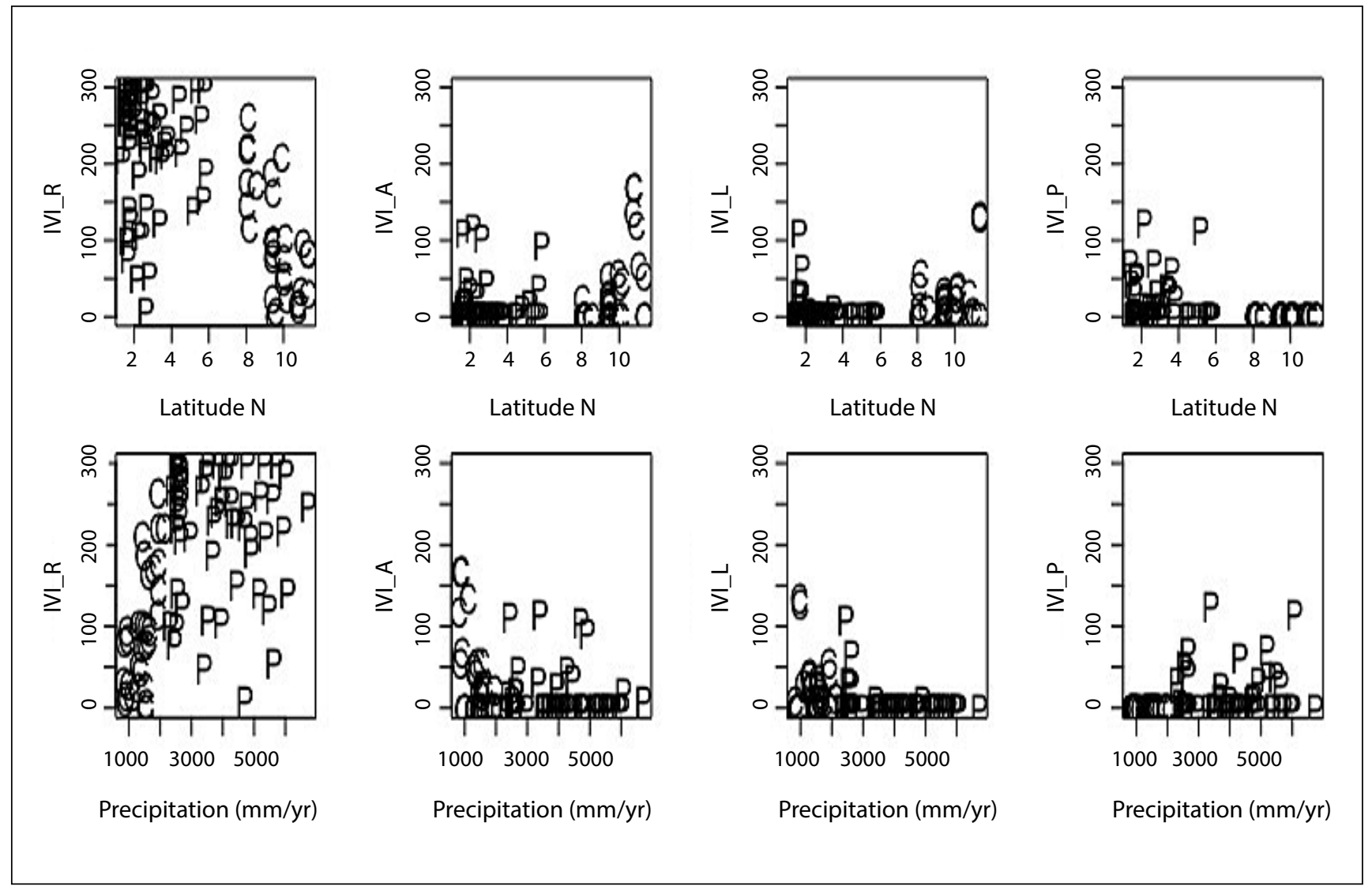

Figure 2. Geographical variation of the Importance Value Index (IVI) for Rhizophora (R), Avicennia (A), Laguncularia (L) and Pelliciera (P) relative to latitude (Lat) and total annual rainfall (Bio12 extracted from WorldClim). Basins are shown with point characters: C: Caribbean, P: Pacific. Plotting example using R statistical software 


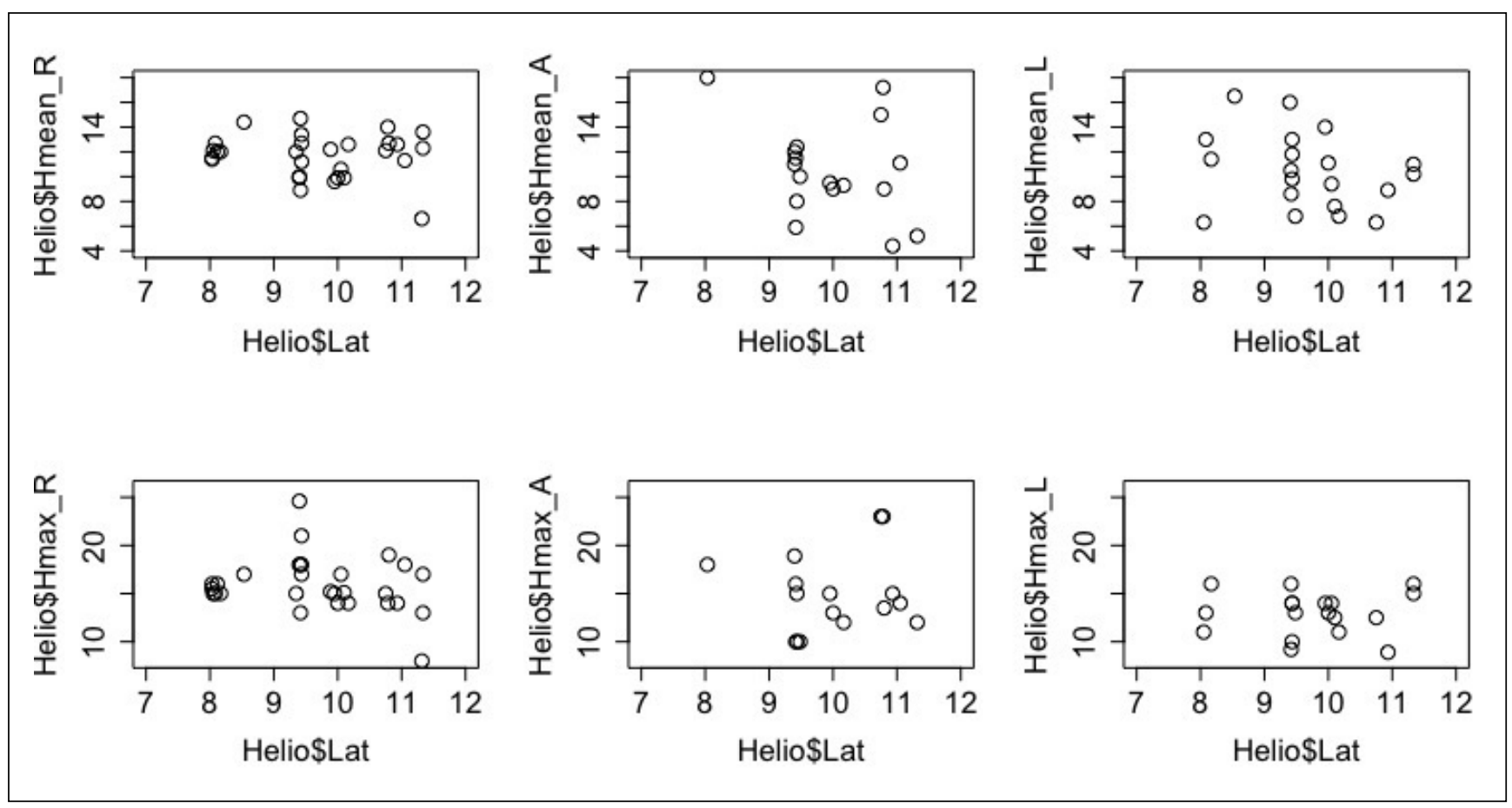

Figure 3. Mean (Hmean) and maximum (Hmax) tree height per mangrove stand relative to latitude (Lat) along the Caribbean coast. "Helio" stands for the name of the database.

to its greatest density and high mean $\mathrm{DBH}$. The importance of $A$. germinans is related to the high diameter, exceeding that of Rhizophora in some locations.

According to the IVI, there are marked differences both floristically and structurally between the Pacific and Caribbean coasts (Figure 2). When data were separated between the Pacific and the Caribbean locations, there was a clear shift in IVI with Rhizophora being more important in the former and A. germinans in the latter (Supplementary file, https://www.raccefyn.co/index.php/raccefyn/article/ downloadSuppFile/780/3362 and Figure 4). The IVI of $L$. racemosa was greater in the Caribbean than in the Pacific while for $P$. rhizophorae the pattern was the opposite. Moreover, along the mainland Caribbean coast, there is a well-defined gradient in a northeastern direction: while the IVI of $A$. germinans (black mangrove) increased, the IVI of $R$. mangle decreased. When the IVI was plotted against gridded-precipitation-data extracted from WorldClim (Hijmans, et al., 2005, Fick \& Hijmans, 2017) (Figure 2 ), the resulting patterns agreed with those reported in the literature based in summaries from geographically dispersed and independent studies conducted with different methods (Urrego, 2018). Consistent with an increase in aridity towards the Guajira Peninsula in limits of the Gulf of Venezuela, black mangrove stands were usually of low stature in the northernmost area (precipitation $<500$ $\mathrm{mm} /$ year) while red mangrove stands were taller in the southernmost area, i.e., the Gulf of Urabá in the proximity to the Isthmus of Panamá dominated by a semi-humid (seasonally wet) climate $(2,500 \mathrm{~mm} / \mathrm{year})\left(\mathrm{See} \mathrm{H}_{\text {mean }}\right.$ and $\mathrm{H}_{\max }$ in Figure 3). The white mangrove L. racemosa did not show a clear geographic pattern. Pelliciera rhizophorae (Piñuelo mangrove) exhibited a discontinuous distribution of small populations in the southern part of the Caribbean (Bolívar, Córdoba, and Antioquia). It was proposed that populations of this species went extinct in many locations of the Southern Caribbean after the closure of the Isthmus of Panamá as a consequence of the intolerance to high salinity conditions (Blanco-Libreros, et al., 2016, and references therein). Nowadays, remnant populations are present in the major river deltas: Canal del Dique, Sinú River, and Atrato River. Finally, although not included in HELIO_SP.CO v.1 due to the geographical isolation, the San Andrés and Providence Archipelago, a maritime territory close to the coast of Nicaragua (Central America), is known for the presence of highly productive ( $c a .15 \mathrm{Mg} / \mathrm{ha} / \mathrm{yr}$ ), mixed-species stands seemingly supported by freshwater underground runoff reaching the coastal plain depressions under the karstic basement (García-Hansen, et al., 2002; Sánchez-Núñez \& Mancera-Pineda, 2011).

Along the Pacific Coast, extending perfectly on the latitudinal axis (South-North), mangrove species also showed a marked geographic pattern, which was more related with geomorphology than with climate (Figure 2: but notice the lack of sampling points in areas further north in the Pacific and in the Darién-Chocó region where areas with small mangroves have been reported). All species showed sharp changes in the IVI relative to Cabo 


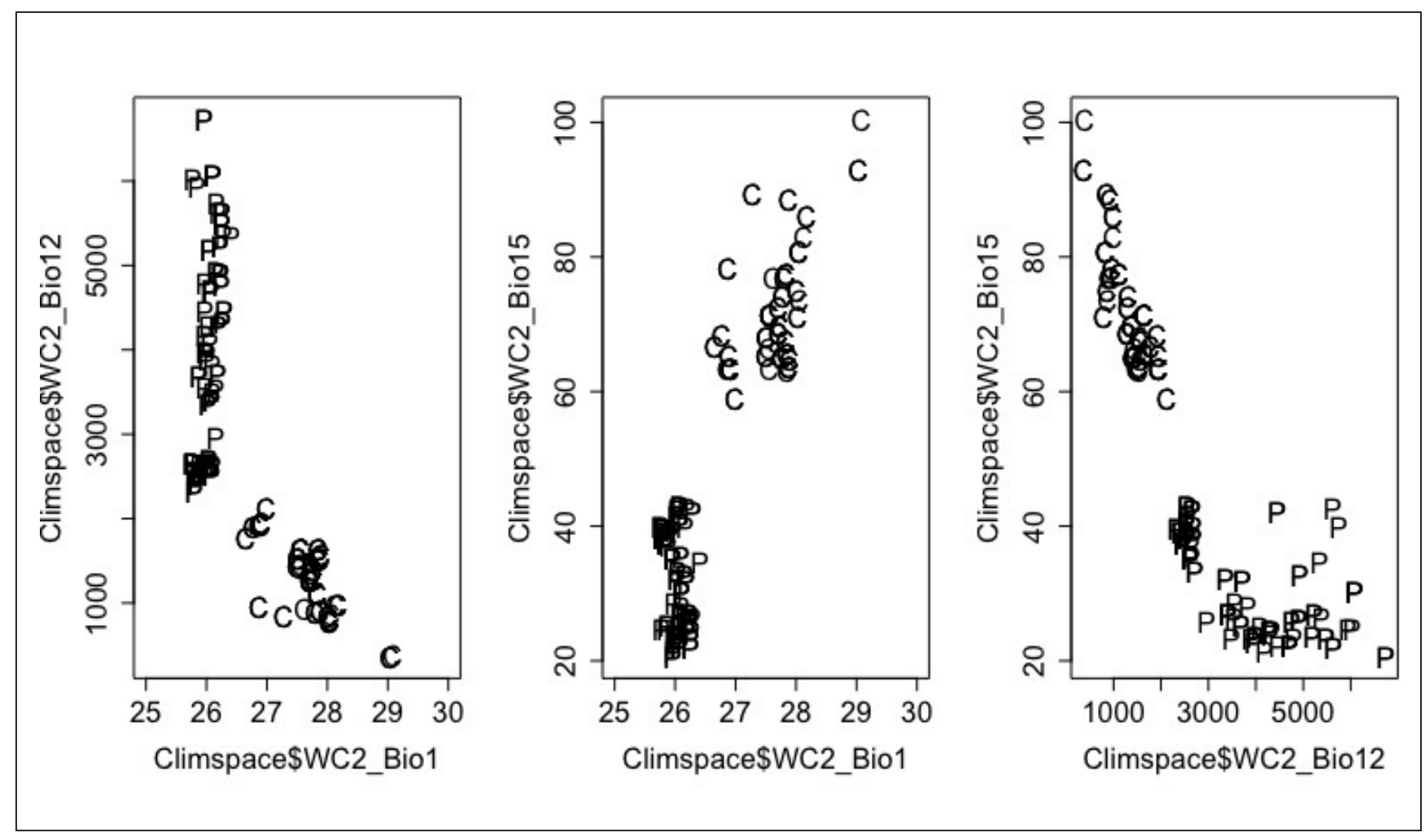

Figure 4. Climate space of mangroves in Colombian coasts (C: Caribbean; P: Pacific) using selected variables extracted from WorldClim2: Bio1 = annual mean temperature (Celsius degrees), Bio12 = annual precipitation $(\mathrm{mm})$, Bio15 = precipitation seasonality (coefficient of variation)

Corrientes, a major basalt salient located at the Central part of the Pacific coast, marking the southern limit of Serranía del Baudó, a volcanic coastal relief extending to the North in the limit with Panama. It emerged nearly 3 million years before present as a consequence of the rise of the Isthmus of Panamá (O'Dea, et al., 2016). Therefore, the coastal plain where mangroves develop extends less than 1-5 km to the North of Cabo Corrientes, but it broadens $10 \mathrm{~km}$ to the South. Moreover, freshwater runoff occurs as small streams springing from altitudes 100 to $500 \mathrm{~m}$ a.s.l. reaching the ocean within a few kilometers $(<5-10 \mathrm{~km})$. On the narrow coastal platforms north from Cabo Corrientes, P. rhizophorae reached the greatest IVI forming monospecific stands in the embayments receiving the largest freshwater discharge. This species is found to the south of Cabo Corrientes with a lower IVI, usually occurring together in mixed stands with other species, although small monospecific stands were also found (Pinto-Nolla, 1999; Estero Aguadulce, Buenaventura Bay, JFBL personal observations). To the north of Cabo Corrientes, the black mangrove (A. germinans) exhibited a very low IVI, but it increased to the south. This species was commonly found in mixed stands, but formed monospecific stands in the channels behind barrier islands located on the front of the deltaic fans of the major southern Pacific rivers. The red mangrove Rhizophora spp. exhibited the largest IVI along the Pacific coast, but differences were evident relative to Cabo Corrientes. In the northern coast, it was lower because the species was found as a narrow (low stature) fringe surrounding P. rhizophorae stands. On the contrary, in the southern coast, Rhizophora spp. was found forming extensive, monospecific or mixed species forests covering the deltaic islands of major rivers. They were also found upstream as riverine mangroves or as fringe mangroves surrounded by rocky cliffs in major embayments favored in both cases by the meso- to macro-tidal regime. It is discussed that the tallest and most extensive red mangrove stands are found in the Mira River, close to the border with Ecuador. The white mangrove $L$. racemosa did not show a geographic pattern similarly as in the Caribbean.

The WorldClim2 data (Fick \& Hijmans, 2017) extracted for MCP locations (see Dataset 2 in HELIO_SP.CO v.1) depict the interesting climatic framework for mangrove species occurrence and development (Figure 4). They also provided a more continuous figure of the north-south, east-west, arid to super-humid climatic gradient along the Colombian coast than that offered by the limited coverage of the Instituto de Hidrología, Meteorología y Estudios Ambientales (IDEAM) climatic stations because other sources were also employed. Using bi-dimensional climatic spaces ("Climspace" in Figure 4) which combine Biol (mean annual temperature), Bio12 (total annual pre-cipitation), and Bio15 (precipitation seasonality), it was clear that there are differences between 
the coasts, but also that gradients within each of them vary depending on the variable. Total precipitation is correlated with the mean annual temperature at a national scale, but more markedly along the Caribbean. It is also correlated with precipitation seasonality. Along the Pacific, there is variability in both rainfall descriptors, but not in mean annual temperature. Therefore, such patterns are the template to study the effects of the current climate on mangrove species distribution, individual ecophysiology, population dynamics, community assembly, and ecosystem function. It is also an opportunity to explore region-dependent consequences of future climate changes in terms of precipitation magnitude and variability and of temperature. As an example, we illustrate here current and pre-2001 climatic spaces for mangroves species using HELIO_SP.CO v.1 (Figure 5). Rhizophora spp. was broadly reported, particularly along the Pacific, but it did not occur above $28,5^{\circ} \mathrm{C}$ in the Caribbean. The occurrence of $A$. germinans was less frequent across the climatic space, but it was not limited by temperature, which suggests the interplay of site-specific variables such as sediments, geomorphology, and biotic interactions, among others. A similar pattern was observed in L. racemosa that scored a lower number of occurrences, but dispersed within the whole breadth of the climatic space suggesting the importance of other drivers. Considering the occurrence of trees with a $\mathrm{DBH}$ $>15 \mathrm{~cm}, P$. rhizophorae was not present in the Caribbean, which points to gaps in the completeness of the database and the scarcity of populations along this coast, as discussed previously, and is consistent with historical biogeographic drivers. Nonetheless, its occurrence along a wide spectrum of annual rainfall across the Pacific suggests the interactions with other local factors. Although an in-depth explanation of these patterns is beyond the scope of this paper, the lack of correlation between climatic variables and occurrences of Avicennia and Laguncularia could be explained either by a greater importance of local scale drivers (e.g., geomorphic settings, anthropogenic disturbance regime) or by an actually lower limitation of climate variables within the geographical extent in Colombia. On the contrary, Rhizophora spp. seems to be the only species affected by aridity in the northern Caribbean coast. At hemispheric and global scales, species occurrences are clearly correlated with climatic variables, particularly at their limits of distribution (RiveraMonroy, et al., 2017).

Interesting patterns would surely emerge at national and regional scales when considering other variables such as density, $\mathrm{DBH}$, and height so we expect that the MCP database, partially available in HELIO_SP.CO v.1 would be a useful resource for biogeographical and macroecological analyses when combined with climatic, geologic and landuse databases (see the example for Colombian terrestrial forests in Álvarez-Dávila, et al., 2017). It is an urgent need to incorporate the use of open databases for Colombian mangroves because those for terrestrial forests such as ForestGeo (Anderson-Texeira, et al., 2015) and a wide range of taxonomic groups such as BioTime (Dornelas, et $\boldsymbol{a l . , 2 0 1 8 )}$ are proving to be instrumental to understand the ecological consequences of climate change and other anthropogenic drivers. Under the current environmental change trends in Colombia, it is important to update the national mangrove inventory and establish long-term monitoring programs in specific sites.

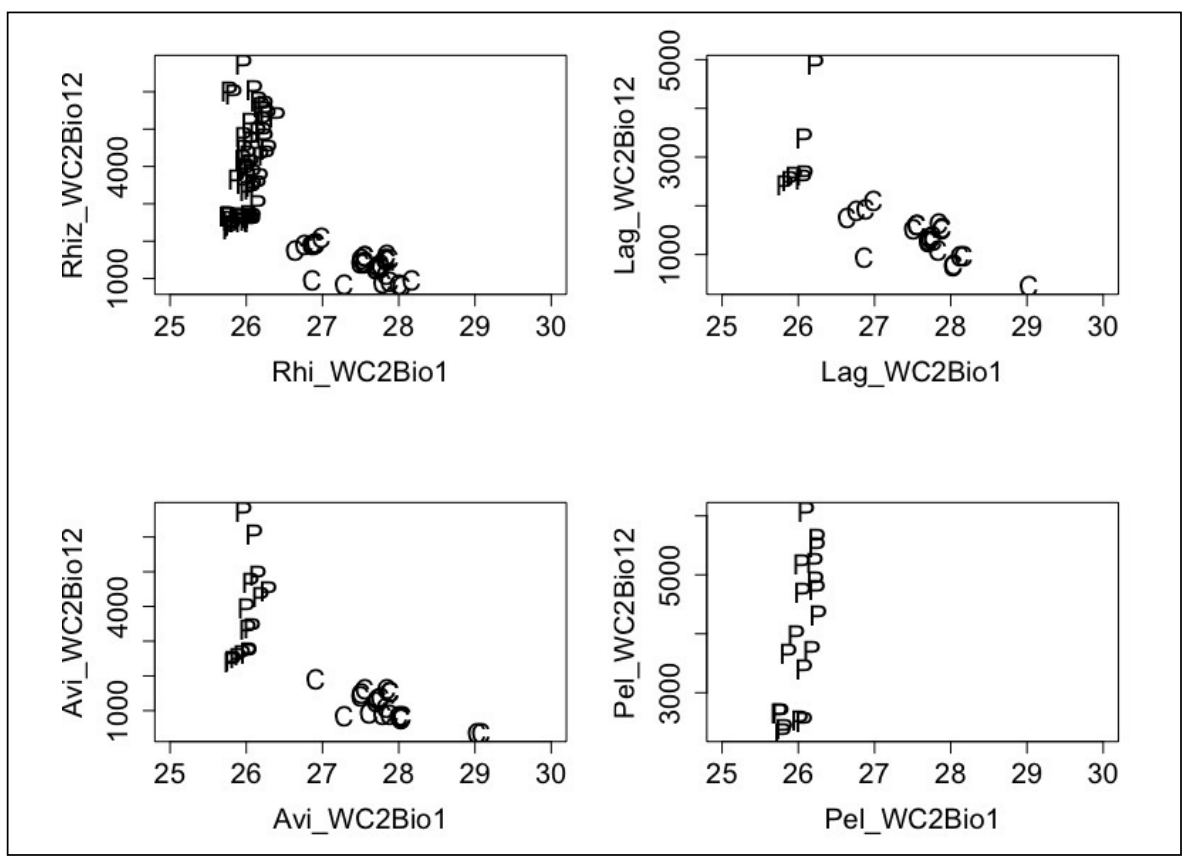

Figure 5. Biplots of WC2Biol (annual mean temperature, Celsius degrees) and WC2Bio12 (annual precipitation, mm) indicating occurrences of each mangrove species in Colombian coasts (C: Caribbean; P: Pacific) 


\section{Progress in research and management, 1997-2017}

A bibliography of mangrove information was compiled and published for the first time in 1997 as part of the MCP (Álvarez-León, 1997) and the compilation was continued after 1997 in order to assess the progress. Additionally, a high number of papers in national and international journals and various books, unpublished reports, undergraduate and post-graduate theses were included. However, only a fraction of these reports, which provide useful historical background, have been published in national and international journals. At a quick glance, it is easy to note the increasing number of mangrove studies in Colombia: 119 in 1984 a, 160 in 1984 b, 438 in 1992, 1,114 in 1997, and 1,226 in 2016 (Álvarez-León, 1984a, 1984b, 1992, 1997, 2016) mainly on biodiversity assessments, fisheries, land-use conflicts, and climate change. Álvarez-León (2003) also summarized the advances in restoration and management. More recently, the legal framework and other aspects of mangrove management have also been summarized (García \& PolaníaVorenberg, 2007; Uribe-Pérez \& Urrego-Giraldo, 2009; Sierra-Correa \& Cantera-Kintz, 2015; Álvarez-León \& Álvarez-Puerto, 2016). The largest mangrove areas in the Colombian continental Caribbean region are found in Ciénaga Grande de Santa Marta (Rivera-Monroy, et al., 2006), Cispatá Bay (Agudelo, et al., 2015), and the Gulf of Urabá (Blanco-Libreros, et al., 2012, Urrego, et al., 2014), which continue to be preferred sites for research projects. In the Pacific coast, Málaga Bay (partially protected as part of the Uramba National Natural Park and the Distrito de Manejo Integrado La Plata) has been a place of recent advances in mangrove science (Castellano-Galindo, et al., 2013; Riascos, et al., 2018). Finally, despite its isolation from the Colombian mainland and its distinctive mangrove ecology drivers, San Andrés Island continues to be an active research site (Sierra-Rozo, et al., 2009; PolaníaVorenberg, et al., 2015). Further updates of mangrove research performed across the country by the Universidad Nacional de Colombia can be found in Polanía-Vorenberg, et al. (2015).

Regarding mangrove management, zoning was definitively established as the main tool for all coastal Colombian departments (Ministry of the Environment Resolutions No. 1602 , December $21^{\text {st }}, 1995$; No. 0020, January $9^{\text {th }}, 1996$; No. 0257, March $26^{\text {th }}, 1997$, No. 0924, October $16^{\text {th }}, 1997$; 0233, March 29 $9^{\text {th }}$, 1999) (Álvarez-León \& Álvarez-Puerto, 2016). Since 2001 all department-level environmental agencies were urged to provide a fine scale zoning. Such zoning updated the mangrove area in Colombia to 285,050 ha in 2011 (Caribbean: 90,170 ha; Pacific: 194,880 ha) (http:// www.minambiente.gov.co) (INVEMAR, 2014). A decade later, many of the initial zonings have been modified to some extent to solve land-use conflicts, to lease port activities and other coastal infrastructure developments, and to declare coastal protected areas. The zoning in the Department of Antioquia was the first to be updated supported by a new methodology based on GIS advances (Ministry of the Environment and Sustainable Development Resolution 005, January 2017). This methodology was recently included as part of the standards for the mandatory update of mangrove zoning nation-wide (Resolution 1263, July 2018). The Instituto de Investigaciones Marinas y Costeras "Benito Vives de Andreis" (INVEMAR), the Colombian advisory research institution for marine and coastal ecosystems, recently launched two new online platforms for managing mangroves: The Colombian geographic information system for mangroves (Sistema de Información para la Gestión de los Manglares en Colombia - SIGMA, http://sigma.invemar. org.co) and the tool for monitoring and surveillance of mangroves (EGRETA, http://cinto.invemar.org.co/egreta). In this sense, it would be useful to integrate HELIO_SP.CO v.1 to such platforms.

\section{Major challenges ahead}

Both coasts in Colombia are facing challenges related with climate change and socioeconomic development. First, mangroves are threatened by sea-level rise (BlancoLibreros, 2016, and references therein). This issue is especially severe in the Caribbean coast where various major cities such as Cartagena and the surrounding mangroves are being flooded due to sea-level rise in interaction with storm surges and coastal infrastructure (Andrade-Amaya, et al., 2017). In addition, there are various erosion hotspots threatening both coastal infrastructure and mangroves, for example, in portions of Córdoba and Antioquia (Correa \& Vernette, 2004; Blanco-Libreros, 2016). In the Pacific coast, the southern part in the proximity to the border with Ecuador is threatened by relative sea-level rise induced by local and regional subsidence of the coast (López, et al., 2008). In addition, there are land-use conflicts particularly along the Caribbean region and in general in the proximity to major port cities nation-wide. For instance, the ecological monitoring of land-use changes along the coast of Turbo (Antioquia), located in the southwestern end of the Caribbean coast, has provided the evidence of changes in ecosystem integrity from population to landscape variables as the consequence of cumulative anthropogenic disturbances such as illegal logging and clearing, conversion to pasturelands, and the placement of infrastructure such as powerlines in interaction with natural disturbances such as coastal erosion and sedimentation (Figure 6) (Blanco-Libreros, et al., 2013; Blanco-Libreros \& Estrada-Urrea, 2015; BlancoLibreros, 2016). Such processes have induced change rates ranging between $-1,2$ and 0,8 \%/year (Blanco-Libreros \& Estrada-Urrea, 2015; Blanco-Libreros, 2016).

In this context, the inclusion of the MCP databases in decision-making processes will be useful for regional planning and adaptation to climate change. This has become an urgent task particularly in the Pacific coast after the peace agreement with FARC was signed in 2016, as it designated areas for agricultural-based development programs 


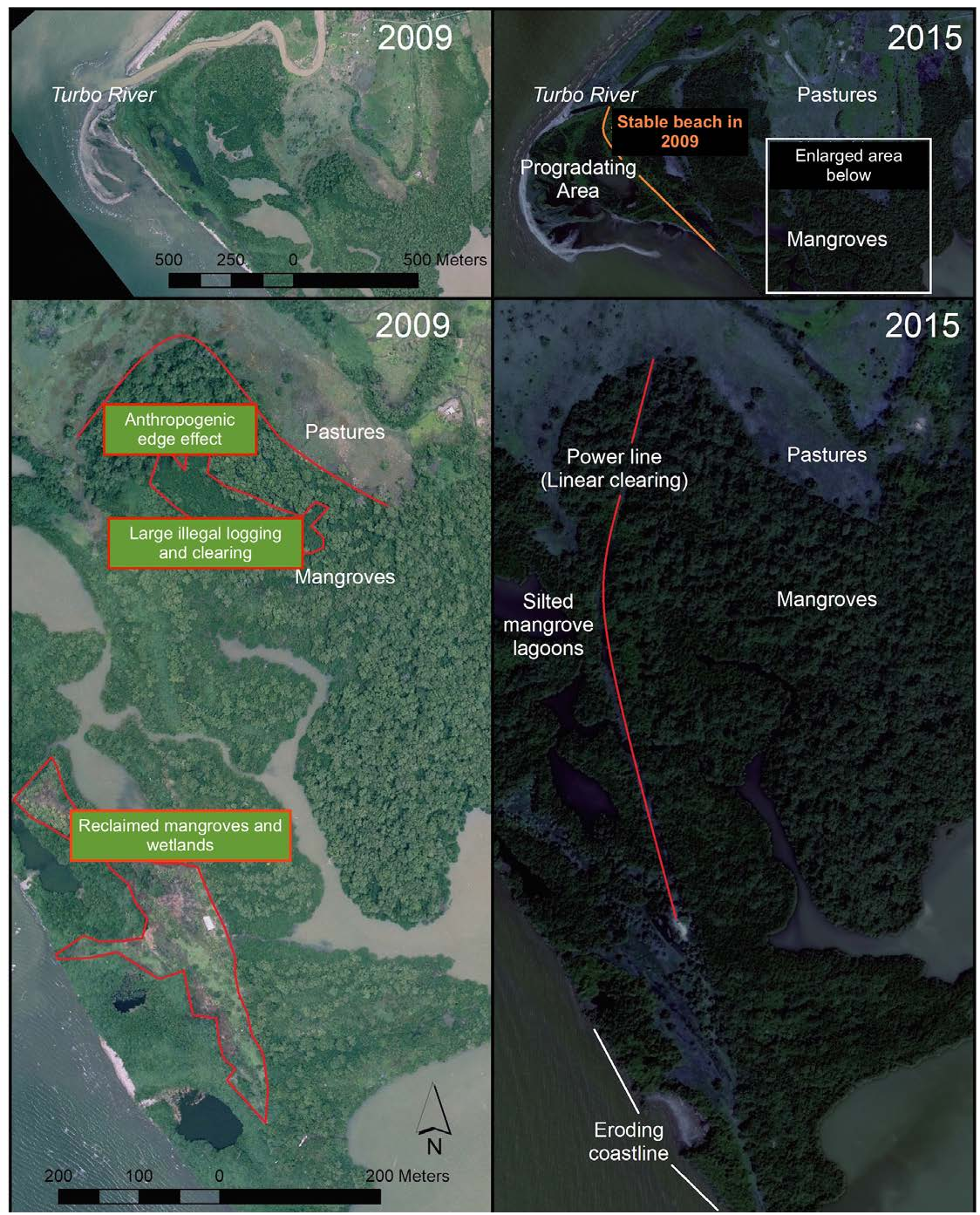

Figure 6. Cumulative anthropogenic and natural disturbances in El Uno Bay (Turbo, Antioquia), a coastal lagoon in the Southwestern Caribbean. See sharp pasture-to-mangrove edges and clearings in 2009, indicating an anthropogenic landscape. Note cumulative changes in 2015: Areas of progradation and erosion and installment of a power line producing permanent linear clearing. 2009: Ortophotographic mosaic (resolution: $30 \mathrm{~cm}$ ). 2015: Worldwiew satellite image (resolution: $1 \mathrm{~m}$ ).

in several rural areas near the coast or upstream to major deltas and mangrove areas (in Nariño: Tumaco, Francisco Pizarro, Mosquera, La Tola, as well as others in Cauca and Valle del Cauca) (Agencia para la Renovación del Territorio - ART, 2017), which would entail a change in the socioeconomic scenario. Extensive parts of the Pacific coastal landscape have seemingly experienced low rates of deforestation or even reached a steady coexistence state of agricultural cover and native forests (López-Angarita, et al., 2018, Mejía-Rentería, et al., 2018). In contrast, despite the peace treaty, oil spills from bombings by remnant dissident groups may continue to affect mangroves in the Tumaco Bay and deforestation might advance into areas formerly dominated by FARC as has been already documented for upland forests and protected natural areas (Baptiste, et al., 2017, Salazar, et al., 2018, Armenteras, et al., 2018). In the Caribbean coast, the extensive mangrove area in the Urabá region in Antioquia would be affected by the socioeconomic changes expected in the post-conflict period associated with both the designation of territorycentered development plans (Programas de Desarrollo con Enfoque Territorial, PDET) (ART, 2017) and the operation of international ports (Puerto Antioquia in Bahía Colombia, Turbo, http://www.minambiente.gov.co/images/normativa/ resoluciones/2012/res_0032_250112.PDF). Therefore, it is necessary to have a baseline of the state of mangroves and other coastal wetlands and to build a monitoring network similar to the one proposed for terrestrial forests (Sierra, et al., 2017, Salazar, et al., 2018). Such baseline may be drawn by using open, department- and nation-wide data (such as those included in HELIO_SP.CO v.1) and other initiatives involving more MCP data. The network of sampling plots 
deployed during the MCP could be also used either as the blueprint for defining future monitoring networks or as control points for remotely sensed inventories given that field data and allometric equations would be readily available for validation (Simard, et al., 2008). In addition, this network would be also helpful in designating field sites for nationwide mangrove zone updating and to estimate deforestation rates or stand growth (Ministry of the Environment, Resolution 1263, July 2018).

Finally, by committing to achieve the Aichi Convention Conservation Targets, the Colombian Government has promised to increase the protected natural areas in both extent and number. Accordingly, two new protected areas recently declared under a co-management scheme included extensive mangrove areas: the regional district of integrated management in Bajo Baudó (Chocó) and the national one in Cabo Corrientes (Nariño). Additional conservation areas could be declared using co-management schemes, particularly in carbon-rich mangroves (blue carbon) and areas providing a variety of ecosystem services to coastal livelihoods. For instance, the growing volume of research in Cispatá Bay (Córdoba) and the Atrato River delta (Antioquia) has resulted in identifying such blue carbon-based opportunities for conservation and socioeconomic development of fishing communities (Blanco-Libreros, et al., 2015; Yepes, et al., 2016; Bolívar, et al., 2018). The major long-term large-scale monitoring program on mangroves in Colombia, located in Ciénaga Grande de Santa Marta, has proven the importance of using big datasets for addressing management-oriented questions (e.g., climate warming and water-use change) (Rodríguez-Rodríguez, et al., 2016; Jaramillo, et al., 2018). Surely, solving other challenges, yet to be identified by scientists, resource managers, and urban and regional planners, would benefit from using open datasets.

\section{Conclusion}

The major national mangrove inventory undertaken in Colombia to date (MCP) has made important contributions in terms of technical reports, management policy guidelines, and preliminary zoning of mangrove areas nation-wide. Moreover, it has promoted the update of mangrove inventories and the zoning at the department level and it has also stimulated research programs in particular geographic areas (e.g., in Cispatá and Urabá). Equally important, the MCP produced large datasets that have served for specific purposes, which should be appreciated, reviewed, and used to advance in mangrove science and management in the coming years. In the present study, we resorted to the HELIO_SP.CO v.1 database for information on stand-level variables for more than 100 sites along Colombia's mainland coasts collected between 1995 and 1996 clearly describing climate-related latitudinal gradients in species IVI and height. We expect that this database may be instrumental for addressing macroecological and biogeographical questions and hypotheses. In combination with other open datasets, the HELIO_SP.CO v.1 might also be useful for addressing applied questions and for supporting decision-making processes related to mangrove conservation and planning in the coastal zone under the country's new climatic and political scenarios. It is also expected that HELIO_SP.CO v.1 and future outgrowths would help to face the challenges and opportunities for Colombia as part of global mangrove conservation efforts. We also suggest that other datasets generated by researchers since 2000 would be made available to the scientific community. Together with the baseline provided by the MCP, such datasets could help to render an updated view of mangrove trends and conservation in Colombia and to identify target areas for establishing monitoring programs.

\section{Supplementary information}

See Supplementary Material in: https://www.raccefyn.co/index. php/raccefyn/article/downloadSuppFile/780/3362

\section{Acknowledgments}

To Heliodoro Sánchez-Páez and the many participants in the different stages of the MCP for collecting, entering and processing these valuable datasets. JFB acknowledges funding for different projects over the years to support data entry, validation of the MCP data, and to gather evidences of natural and anthropogenic changes in the Gulf of Urabá mangroves (Antioquia). We also thank the Universidad de Antioquia research committee (CODI) for funding satellite imagery and verification of recent dynamics in Turbo (Antioquia) in the context of the projects "Estrategia de Sostenibilidad para el grupo ELICE" and "Fragmentación del manglar por la instalación de un tendido eléctrico: evidencias desde la evaluación de un manglar sub-urbano (bahia El Uno, Turbo)". The authors greatly appreciate the comments provided by the two anonymous reviewers that helped to improve the manuscript.

\section{Conflicts of interest}

None.

\section{Author's contributions}

Both authors conceived the manuscript. JFBL wrote an initial manuscript and obtained input and final approval from RAL. JFBL led data entry, curation and assembly of the final database. RAL provided the historical background and additional data from grey literature related to the project "Mangroves of Colombia".

\section{References}

Agencia para la Renovación del Territorio (ART). (2017). Mapa del Programas de Desarrollo con Enfoque Territorial 
(PDET). Accessed on: 28 de noviembre, 2018. Available at: http://www.renovacionterritorio.gov.co/especiales/especial_ PDET/mapa.html

Agudelo, C.M., Bolívar, J., Polanía-Vorenberg, J.H., UrregoGiraldo, L.E., Yepes, A., Sierra, A. (2015). Estructura y composición florística de los manglares de la Bahía de Cispatá, Caribe colombiano. Rev. Biol. Trop. 63: 1137-1147.

Álvarez-Dávila, E., Cayuela, L., González-Caro, S., Aldana, A.M., Stevenson, P.R., Phillips, O., et al. (2017). Forest biomass density across large climate gradients in northern South America is related to water availability but not with temperature. PLoS ONE. 12: e0171072. Doi: 10.1371/ journal.pone. 0171072

Álvarez-León, R. (1984a). Sinopsis sobre el conocimiento de los ecosistemas de manglar en Colombia. (Primera revisión). In: Álvarez-León, R. (coordinador) Reunión Técnica para el Diseño de un Proyecto Especial sobre Bioecología del Manglar OEA / COLCIENCIAS / INVEMAR, Santa Marta (Mag.) Colombia, junio 27-29 de 1984, p.1-17.

Álvarez-León, R. (1984b). Sinopsis sobre el conocimiento de los ecosistemas de manglar en Colombia. (Segunda revisión). In: Yanine-Díaz, D. (editor) Mem. Sem. Reg. Ordenación Integrada de las Zonas de Manglar FAO / INDERENA, Cali (Valle) -Tumaco (Nar.) Colombia, noviembre 19-23 de 1984, p.1-31.

Álvarez-León, R. (1992). Sinopsis sobre el conocimiento de los ecosistemas de manglar en Colombia. (Tercera revisión). In: Lacerda, L.D. (coordinador) Mem. Workshop on Conservation and Sustainable Utilization of the Mangrove Forest in Latin America and Africa Regions ITTO / ISME / UFF, Niteroi (R.J.) Brazil, mayo 28-30 de 1984, p.1-51.

Álvarez-León, R. (1993). Mangrove ecosystems in Colombia. In: L. D. Lacerda (editor). Conservation and Sustainable Utilization of Mangrove Forest in Latin America and Africa Regions, ITTO / ISME Project PD 114/90 (F). ISME-Tech. Reports (2), p. 75-113.

Álvarez-León, R. (1997). Bibliografía sobre los ecosistemas de manglar en Colombia. (Cuarta revisión). In: Álvarez-León, R. \& Páez-Parra, F.E. (editores.) Proy. PD 171/91 Rev. (F) Fase 1 Conservación y Manejo para el Uso Múltiple y el Desarrollo de los Manglares en Colombia, MMA/OIMT. Santa Fe de Bogotá D. C. Inf. Técnico, 9: 112 p. + 5 anexos, 2 mapas.

Álvarez-León, R. (2003). Los manglares de Colombia y la recuperación de sus áreas degradadas: revisión bibliográfica y nuevas experiencias. Rev. Madera y Bosques. 9: 3-25.

Álvarez-León, R. (2016). Sinopsis de las investigaciones realizadas en los ecosistemas de manglar de Colombia, entre 1997 y 2016. II Seminario-Taller Internacional de Estuarios \& Manglares: "Fuentes de desarrollo humano en las zonas costeras e insulares. Herramientas para su estudio \& manejo". Universidad del Valle. Cali (Valle) Colombia, Marzo 24 al 26 de 2015.

Álvarez-León, R. \& Polanía-Vorenberg, J.H. (1994). Manglares, lagunas costeras y estuarios del Caribe colombiano. In: J.J. Escobar-Ramírez \& J.R. Cantera-Kintz (editors). Memorias. Taller de Expertos sobre el Estado del Conocimiento y Lineamientos para una Estrategia Nacional de Biodiversidad en los Sistemas Marinos y Costeros, CCO / ENB / COLCIENCIAS. Minca (Mag.) Colombia, agosto 3-5 de 1994. $311 \mathrm{p}$.
Álvarez-León, R. \& Polanía-Vorenberg, J.H. (1996). Los manglares del Caribe colombiano: síntesis de su conocimiento. Rev. Acad. Colomb. Cienc. 20: 447-464.

Álvarez-León, R. \& García-Hansen, I. (2003). Biodiversity associated with mangrove in Colombia. ISME / GLOMIS Electronic Journal. 3: 1-2.

Álvarez-León, R. \& Álvarez-Puerto, J.R. (2016). Legislación colombiana relacionada con los ecosistemas de manglar. UFC- Arq. Cien. Mar. 49: 115- 131.

Anderson-Texeira, K., Davies, S.J., Bennett, A.C., González-Akre, E.B., Muller-Landau, H.C., Wright, S.J., et al. (2015). CTFS-ForestGEO: A worldwide network monitoring forests in an era of global change. Glob. Change Biol. 21: 528-549.

Andrade-Amaya, C.A., Ferrero-Ronquillo, A.J., León-Rincón, H., Mora-Páez, H., Carvajal-Perico, H. (2017). Sobre cambios en la línea de costa entre 1735 y 2011 y la subsidencia en la bahía de Cartagena de Indias, Colombia. Rev. Acad. Colomb. Cienc. Ex. Fis. Nat. 41: 94-106.

Armenteras, D., Schneider, L., Dávalos, L.M. (2018). Fires in protected areas reveal unforeseen costs of Colombian peace. Nature Ecol. Evol. Nature Ecology \& Evolution. 3: 20-23. Doi: 10.1038/s41559-018-0727-8

Baptiste, B., Pinedo-Vásquez, M., Gutiérrez-Vélez, V.H., Andrade, G.I., Vieira, P., Estupiñán-Suárez, L.M., Londoño, M.C. Laurance, W., Ming-Lee, T. (2017). Greening the peace in Colombia. Nature Ecol. Evol. 1: 3. Doi: 10.1038/s41559-017-0102

Blanco-Libreros, J.F. (2016). Cambios globales en los manglares del golfo de Urabá (Colombia): entre la cambiante línea costera y la frontera agropecuaria en expansión. Actual. Biol., 38: 53-70.

Blanco-Libreros, J.F., Estrada-Urrea, E.A., Ortiz-Acevedo, L., Urrego, L.E. (2012). Ecosystem-wide impacts of deforestation in mangroves: The Urabá Gulf (Colombian Caribbean): Case study. ISRN Ecology. 2012: 1-14.

Blanco-Libreros, J.F., Taborda-Marín, A., Amortegui-Torres, V., Arroyave-Rincón, A., Sandoval, A., Estrada-Urrea, E.A. et al. (2013). Deforestación y sedimentación en los manglares del golfo de Urabá: síntesis de los impactos sobre la fauna macrobéntica e íctica en el delta del río Turbo. Gestión y Ambiente. 16: 19-36.

Blanco-Libreros, J.F. \& Estrada-Urrea, E.A. (2015). Mangroves on the edge: Anthrome-dependent fragmentation influences ecological condition (Turbo, Colombia, Southern Caribbean). Diversity. 7: 206-228.

Blanco-Libreros, J.F., Ortíz-Acevedo, L.F., Urrego, L.E. (2015). Reservorios de biomasa aérea y de carbono en manglares del Golfo de Urabá (Caribe Colombiano). Actual. Biol. 37: 131-141.

Blanco-Libreros, J.F., Estrada-Urrea, E.A., Pérez-Montalvo, R., Taborda-Marín, A., Álvarez-León, R. (2016). Influencia antrópica en el paisaje de las poblaciones de Pelliciera rhizophorae (Ericales: Tetrameristaceae) más sureñas del Caribe (Turbo, Colombia). Rev. Biol. Trop. 64: 79-94.

Bolívar, J.M., Gutiérrez-Vélez, V.H., Sierra, C.A. (2018). Carbon stocks in aboveground biomass for Colombian mangroves with associated uncertainties. Reg. Stud. Mar. Sci. 18: 145-155.

Castellanos-Galindo, G.A. \& Krumme, U. (2013). Tidal, diel and seasonal effects on intertidal mangrove fish in a highrainfall area of the Tropical Eastern Pacific. Mar. Ecol. Prog. Ser. 494: 249-265. 
Castellanos-Galindo, G.A., Cantera, J.R., Saint-Paul, U., FerrolSchulte, D. (2015). Threats to mangrove social-ecological systems in the most luxuriant coastal forests of the Neotropics. Biodivers. Conserv. 24: 701-704. Doi: 10.1007/ s10531-014-0827-y

Castillo-Cárdenas, M.F., Ramírez-Silva, J., Sanjur, O.I., Toro-Perea, N. (2015). Evidence of incipient speciation in the Neotropical mangrove Pelliciera rhizophorae (Tetrameristaceae) as revealed by molecular, morphological, physiological and climatic characteristics. Bot. J. Linn. Soc. 179: 499-510.

Correa, I.D.N \& Vernette, G. (2004). Introducción al problema de la erosión litoral de Urabá (sector Arboletes-Turbo) costa Caribe colombiana. Bol. Invest. Mar. Cost. 33: 7-28.

Dornelas, M., Antão, L.H., Faye Moyes, F., Amanda E. Bates, A.E., Anne E. Magurran, A.E., Adam, D., Asem A., Akhmetzhanova, A.A., et al. (2018). BioTIME: A database of biodiversity time series for the Anthropocene. Global Ecol. Biogeogr. 27: 760-786.

Estrada-Urrea, E. A., Blanco-Libreros, J.F., Álvarez-León, R. (2010). Patrones estructurales de los manglares en el golfo de Urabá y su relación bio-geográfica con el Caribe y Pacífico de Colombia. pp. 169-174. In: INVEMAR-ACIMAR (eds.) Libro de resúmenes extendidos XIV Seminario Nacional de Ciencias y Tecnología del Mar (SENALMAR). Serie de Publicaciones Especiales INVEMAR No. 21. Santa Marta (Mag.) Colombia.

Fick S.E. \& Hijmans R.J. (2017). WorldClim 2: New 1-km spatial resolution climate surfaces for global land areas. Internat. J. Clim. 37: 4302-4315.

García, C. \& Polanía-Vorenberg, J.H. (2007). Marco conceptual para productos no maderables del bosque en manglares de Colombia. Gestión y Ambiente. 10: 169-178.

García-Hansen, I., Gaviria-Chiquazuque, J., Prada-Triana, M.C., Álvarez-León, R. (2002). Producción de hojarasca de los manglares de la Isla de San Andrés, Caribe colombiano. Rev. Biol. Trop. 50: 273-291.

Guevara-Mancera, O.A. (1998). Manual para la restauración de los bosques de manglar en áreas degradadas del Pacífico colombiano. Ministerio del Medio Ambiente de Colombia, Asociación Colombiana de Reforestadores, Organización Internacional de Maderas Tropicales. Proyecto PD. 171/91 Rev. 2 (F) Fase II (Etapa I). Santa Fé de Bogotá. 16 p.

Hamilton, S. \& Friess, D.A. (2018). Global carbon stocks and potential emissions due to mangrove deforestation from 2000 to 2012. Nature Clim. Change. 8: 240-244.

Hijmans, R.J., Cameron, S.E., Parra, J.L., Jones, P.G., Jarvis, A. (2005). Very high resolution interpolated climate surfaces for global land areas. Internat. J. Clim. 25: 1965-1978.

Instituto de Investigaciones Marinas y Costeras - INVEMAR. (2014). Informe del estado de los ambientes y recursos marinos y costeros en Colombia: Año: 2013. Serie de Publicaciones Periódicas No. 3. Santa Marta. 192 p.

Jaramillo, F., Licero, L., Åhlen, I., Manzoni, S., RodríguezRodríguez, J.A., Guittard, A., et al. (2018). Effects of hydroclimatic change and rehabilitation activities on salinity and mangroves in the Ciénaga Grande de Santa Marta, Colombia. Wetlands. 38: 755-767.

López, S.A., Mora-Páez, H. Monroy, C.A., Restrepo, J.D., Restrepo, J. C., Rodríguez-Rubio, E. (2008). Nivel rela- tivo del mar en la costa pacífica sur de Colombia: variabilidad, tendencias e implicaciones en la dinámica deltaica. Bol. Geol. 42: 53-66.

López-Angarita, J., Tilley, A., Hawkins, J.P., Pedraza, C., Roberts, C.M. (2018). Land use patterns and influences of protected areas on mangroves of the Eastern tropical Pacific. Biol. Conserv. 227: 82-91.

Mejía-Rentería, J.C., Castellanos-Galindo, G., Cantera-Kintz, J.R., Hamilton, S.E. (2017). A comparison of Colombian Pacific mangrove extent estimations: Implications for the conservation of a unique Neotropical tidal forest. Estuar. Coast. Shelf Sci. 212: 233-240.

O'Dea, A. Lessios, H. A., Coates, A.G., Eytan, R.I., RestrepoMoreno, S.A., Cione, A.L., et al. (2016). Formation of the Isthmus of Panama. Sci. Adv. 2: e1600883. Doi: 10.1126/ sciadv. 1600883

Osland, M., Gabler, C.A., James, B. Grace, J.B., Day, R.H., Meagan L., McCoy, M.L., McLeod, J.L., et al. (2018). Climate and plant controls on soil organic matter in coastal wetlands. Glob. Change Biol. 00: 1-19. https://doi. org/10.1111/gcb.14376

Peh, K.S.H., Lewis, S.L., Lloyd, J. (2011). Mechanisms of monodominance in diverse tropical tree-dominated systems. J. Ecol. 99: 891-898.

Pinto-Nolla, F.H. (1999). Sucesión y fisionomía de los manglares de Colombia. Rev. Acad. Colomb. Cienc. 23: 141-161.

Polanía-Vorenberg, J.H., Urrego-Giraldo, L.E., Agudelo-Palacio, C.M. (2015). Recent advances in understanding Colombian mangroves. Acta Oecol. 63: 82-90.

Riascos, J.M., Cantera-Kitz, J.R., Blanco-Libreros, J.F. (2018). Growth and mortality of mangrove seedlings in the wettest Neotropical mangrove forests during ENSO: Implications for vulnerability to climate change. Aquat. Bot. 147: 34-42.

Rivera-Monroy, V. H., Twilley, R.R., Mancera-Pineda, J.E., Alcántara-Eguren, A., Castañeda-Moya, E., CasasMonroy, O., et al. (2006). Aventuras y desventuras en Macondo: rehabilitación de la Ciénaga Grande de Santa Marta, Colombia. Rev. Ecotropicos. 19: 72-93.

Rivera-Monroy, V.H. (2017). Advancing mangrove macroecology. In: Rivera-Monroy V.H., Lee, S. Y., Kristensen, E., Twilley, R.R. (editors.) Mangrove Ecosystems: A global biogeographic perspective. Springer International Pub. AG. p: 347-380.

Rodríguez-Rodríguez, J.A., Mancera-Pineda, J.E., Rodríguez, J.M. (2016). Validation and application of an individual based restoration model for tree mangrove species in Ciénaga Grande de Santa Marta. Caldasia. 38: 285-299.

Saenger, P. (2002). Mangrove ecology, silviculture and conservation. Springer Science, Dordrecht. 360 p.

Sánchez-Núñez, D.A. \& Mancera-Pineda, J.E. (2011). Flowering patterns in three Neotropical mangrove species: evidence from a Caribbean island. Aquat. Bot. 94: 177-182.

Sánchez-Páez, H., Álvarez-León, R., Pinto-Nolla, F.H., SánchezAlférez, A.S., Pino-Renjifo, J.C., García-Hansen, I., Acosta-Peñaloza, M.T. (1997a). Diagnóstico y zonificación preliminar de los manglares del Caribe de Colombia. In: Sánchez-Páez, H. \& Álvarez-León, R. (editors.) Proy. PD 171 / 91 Rev. (F) Fase 1. Conservación y Manejo para el Uso Múltiple y el Desarrollo de los Manglares en Colombia, MMA/OIMT. Santa Fe de Bogotá D. C. (Colombia). p: 1- 511. 
Sánchez-Páez, H., Álvarez-León, R., Guevara-Mancera, O.A., Zamora-Guzmán, A., Rodríguez-Cruz, H., Bravo-Pazmiño, H.E. (1997b). Diagnóstico y zonificación preliminar de los manglares del Pacífico de Colombia, In: Sánchez-Páez, H. \& Álvarez-León, R. (eds.) Proy. PD 171 / 91 Rev. (F) Fase 1. Conservación y Manejo para el Uso Múltiple y el Desarrollo de los Manglares en Colombia, MMA/OIMT. Santa Fe de Bogotá D. C. (Colombia), 343 p.

Sánchez-Páez, H., Ulloa-Delgado, G.A., Álvarez-León, R. (Editors) (1998a). Conservación y uso sostenible de los manglares del Caribe Colombiano. Proy. PD 171 / 91 Rev. (F) Fase 1. Conservación y Manejo para el Uso Múltiple y el Desarrollo de los Manglares en Colombia, MMA / OIMT. Santa Fe de Bogotá D. C. (Colombia). 212 p.

Sánchez-Páez, H., Guevara-Mancera, O. A., Álvarez-León, R. (Editors) (1998b). Conservación y uso sostenible de los manglares del Pacífico Colombiano. Proy. PD 171 / 91 Rev. (F) Fase 1. Conservación y Manejo para el Uso Múltiple y el Desarrollo de los Manglares en Colombia, MMA / OIMT. Santa Fe de Bogotá D. C. (Colombia). 178 p.

Sánchez-Páez, H., Ulloa-Delgado, G.A., Álvarez-León, R. (Editors) (2000). Hacia la recuperación de los manglares del Caribe de Colombia. Proy. PD 171 / 91 Rev. 2 (F) Fase 2, Etapa 2. Conservación y Manejo para el Uso Múltiple y el Desarrollo de los Manglares en Colombia, MMA/OIMT. Santa Fe de Bogotá D. C. (Colombia). 294 p.

Sánchez-Páez, H., Ulloa-Delgado, G.A., Tavera-Escobar, H.A. (2004). Manejo integral de manglares por comunidades locales, Caribe de Colombia. Proyecto OD 60/01 REV.1 (F): "Manejo sostenible y restauración de los manglares por comunidades locales del Caribe Colombiano". Ministerio de Ambiente Vivienda y Desarrollo Territorial-CONIFOIMT. Santa Fe de Bogotá D. C. 335 p.

Sierra, C.A., Mahecha, M., Poveda, G., Álvarez-Dávila, E., Gutiérrez-Vélez, V.H., Reuf, B., et al. (2017). Monitoring ecological change during rapid socio-economic and political transitions: Colombian ecosystems in the post-conflict era. Environ. Sci. Pol. 76: 40-49.

Salazar, A., Sánchez, A., Villegas, J.C., Salazar, J.F., RuízCarrascal, D., Sitch, S., et al. (2018). The ecology of peace: Preparing Colombia for new political and planetary climates. Front. Ecol. Environ. 16: 1-7.

Sierra-Correa, P.C. \& Cantera-Kintz, J.R. (2015). Ecosystembased adaptation for improving coastal planning for sealevel rise: A systematic review for mangrove coasts. Marine Policy. 51: 385-393.

Sierra-Rozo, O., Mancera-Pineda, J.E., Santos-Martínez, A. (2009). Velocidad de descomposición de la hojarasca en diferentes sustratos de manglar durante la época de lluvias en San Andrés isla, Caribe colombiano. Bol. Invest. Mar. Cost. 38: 59-84.
Simard, M., Rivera-Monroy, V.H., Mancera-Pineda, J.E., Castañeda-Moya, E., Twilley, R.R. (2008). A systematic method for 3D mapping of mangrove forests based on Shuttle Radar Topography Mission elevation data, ICEsat/ GLAS waveforms and field data: Application to Ciénaga Grande de Santa Marta, Colombia. Remote Sens. Environ. 112: 2131-2144.

Simard, M., Fatoyinbo, L., Smetanks, C., Rivera-Monroy, V.H., Castañena-Moya, E., Thomas, N., Stocken, T.V. (2019). Mangrove canopy height globally related to precipitation, temperature and cyclone frequency. Nature Geoscience. 12: $40-45$.

Ulloa-Delgado, G.A., Rodríguez-Cruz, H., Gil-Torres, W., PinoRengifo, J.C. (1998). Manual sobre técnicas de vivero y restauración de áreas de manglar del Caribe Colombiano. Ministerio del Medio Ambiente de Colombia, Asociación Colombiana de Reforestadores, Organización Internacional de Maderas Tropicales. Proyecto PD. 171/91 Rev. 2 (F) Fase II (Etapa I). Santa Fé de Bogotá. 24 p.

Uribe-Pérez, J. \& Urrego-Giraldo, L.E. (2009). Gestión ambiental de los ecosistemas de manglar aproximación al caso colombiano. Gestión y Ambiente. 12: 57-72

Urrego, L.E. (2018). Cananguchales y manglares: humedales forestales de las zonas bajas tropicales, tan semejantes como contrastantes. Rev. Acad. Colomb. Cienc. Ex. Fis. Nat. 42: 80-95.

Urrego, L.E., Molina, E.C., Suárez, J. (2014). Environmental and anthropogenic influences on the distribution, structure, and floristic composition of mangrove forests of the Gulf of Urabá (Colombian Caribbean). Aquat. Bot. 114: 42-49.

Yepes, A., Zapata, M., Bolívar, J., Monsalve, A., Espinosa, S.M., Sierra-Correa, P.C., Sierra, A. (2016). Tree aboveground biomass allometries for carbon stocks estimation in the Caribbean mangroves in Colombia. Rev. Biol. Trop. 64: 913-926.

Zambrano-Escamilla, C.H. \& Rubiano-Rubiano, D.J. (1997a). Memoria de los mapas de los bosques de manglar de la costa Pacífica colombiana, 1969, 1996, y multi-temporal. Inf. Técnico 8. In: Álvarez-León, R. \& Páez-Parra, F.E. (editors). PD 171/91 Rev. 2 (F) Fase I. Conservación\& Manejo para el Uso Múltiple y el Desarrollo de los Manglares de Colombia, MMA / OIMT / ACOFORE. Santa Fe de Bogotá D. C. (Colombia).

Zambrano-Escamilla, C.H. \& Rubiano-Rubiano, D.J. (1997b). Memoria de los mapas de los bosques de manglar del Caribe colombiano: 1996. Inf. Técnico 11. In: ÁlvarezLeón, R. \& Páez-Parra, F.E. (editors). PD 171/91 Rev. 2 (F) Fase I. Conservación\& Manejo para el Uso Múltiple y el Desarrollo de los Manglares de Colombia, MMA/OIMT/ ACOFORE. Santa Fe de Bogotá D. C. (Colombia). 